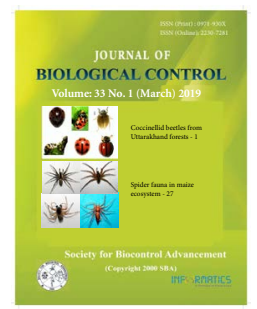

\title{
Impact of integrated pest management modules on natural enemies of whiteflies, Bemisia tabaci (Genn.) in bitter gourd ecosystem
}

\author{
S. ONKARA NAIK ${ }^{*}$, G. S. KANNAN ${ }^{2}$, and A. K. CHAKRAVARTHY ${ }^{1}$ \\ 1. Division of Entomology and Nematology, ICAR-Indian Institute of Horticultural Research, Bengaluru, Karnataka. \\ 2. School of Agriculture and Animal Science, Gandhigram Rural Institute- Deemed University, Gandhigram, Dindigul, \\ Tamil Nadu \\ *Corresponding Author E-mail: onkar632@gmail.com
}

\begin{abstract}
The impact of eight IPM modules on whitefly Bemisia tabaci and its natural enemies were recorded during kharif 2016 and 2017 , rabi-summer 2016-17 and 2017-18. There was a significant difference among the modules in the number of natural enemies per plant. In general, it was found that during rabi-summer the population of $B$. tabaci was higher than the kharif season on bitter gourd. When modules were compared for the population of $B$. tabaci, module 1 to 4 (sowing maize as a barrier crop, removal of infested leaves and residues from the appearance of pests, erection of solar light trap with yellow pan @ 5 traps/ha for trapping, tying yellow sticky trap to attract whiteflies, spraying neem oil @ 1\% and pongam oil @1\%) and module 6 (spraying of Metarhizium anisopliae $\left(2 \times 10^{9}\right)$, Beauveria bassiana $\left(2 \times 10^{8}\right)$, Neem oil 1\% and Pongam oil 1\%) which do not include frequent insecticidal applications recorded higher number of coccinellids, syrphids, hymenopterans and spiders than the IPM modules where frequent applications of chemical insecticides were included as a treatment.
\end{abstract}

Keywords: IPM modules, natural enemies, whiteflies

(Article chronicle: Received: 02-01-2019; Revised: 10-03-2019; Accepted: 25-03-2019)

\section{INTRODUCTION}

Whitefly, Bemisia tabaci Genn. (Hemiptera: Aleyrodidae) is a devastating pest of vegetables, fruits, fibre, plantation crops and ornamental crops in tropical and subtropical regions of the world (Oliveira et al., 2001). Numerous species of natural enemies are recorded on B. tabaci (Gerling et al., 2001; Li et al., 2011; Torres et al., 2014). The natural enemies of B. tabaci occur in diversified agro -ecosystems all around the world, different species predators and parasitoids feed and parasitise on B. tabaci (Nordlund and Legaspi, 1996; Gerling et al., 2001; Palaniswami et al., 2001). Several studies have been conducted on the importance of the beneficial fauna attacking B. tabaci in agricultural systems (Asiimwe et al., 2007; Atuncha et al., 2013). In India studies conducted in Andhra Pradesh, Tamil Nadu and Maharashtra states have also added important information on natural enemies of $B$. tabaci (Natarajan, 1990; Kapadia and Puri, 1991; Rao et al., 1989). In the present study experiments were conducted to assess the impact of eight integrated pest management (IPM) modules on whitefly Bemisia tabaci and its natural enemies in bitter gourd ecosystem during kharif 2016 and 2017, rabi-summer 2016-17 and 2017-18.

\section{MATERIALS AND METHODS}

Except plant protection measures, IPM module included eco-friendly and bio-rational strategies with farmers practice of chemical insecticide sprays (Table 1). Seeds were sown during kharif - 2016, 2017 and rabi-summer 2016-17 and 2017-18. In all the modules including farmers practice and control, bitter gourd seeds were treated with imidacloprid 17.8 SL before sowing in order to manage the early sucking pests and sprayed imidacloprid 17.8 SL @ $0.35 \mathrm{ml} / 1$ on the seedlings three hours before transplanting. The pest management interventions were executed when the pest population crossed economic threshold level.

Observations were recorded at 10 days intervals on three leaves each from top middle and bottom of the 5 randomly selected plants in each replication. Similarly, natural enemy population per plant was also recorded on 5 randomly selected plants in each replication and for parasitoids, under surface of the leaves were examined for parasitism with magnifier hand lens (10X), the parasitised whiteflies turned black. The bitter gourd fruit yield was recorded from each module and the data were presented as in $\mathrm{kg} / \mathrm{ha}$ and benefit cost ratio of each treatment was worked out. Data regarding whitefly damage and viral 
Table 1. Details of IPM Modules

\begin{tabular}{|c|c|}
\hline No. & Module Treatment Details \\
\hline $\mathrm{M}_{1}$ & $\begin{array}{l}\text { Sowing maize as a barrier crop. Removal of infested leaves and residues from the appearance of pests. } \\
\text { Erection of solar light trap with yellow pan @ } 5 \text { traps/ha for mass trapping. Tying yellow sticky trap to } \\
\text { attract whiteflies. }\end{array}$ \\
\hline $\mathrm{M}_{2}$ & $\begin{array}{l}\text { Sowing maize as a barrier crop. Removal of infested leaves and residues from the appearance of pests. } \\
\text { Erection of solar light trap with yellow pan @ } 5 \text { traps/ha for trapping. Tying yellow sticky trap to attract } \\
\text { whiteflies. Releasing of Encarsia guadeloupae } 75,000 / \text { ha @ weekly intervals. }\end{array}$ \\
\hline $\mathrm{M}_{3}$ & $\begin{array}{l}\text { Sowing maize as a barrier crop. Removal of infested leaves and residues from the appearance of pests. } \\
\text { Erection of solar light trap with yellow pan @ } 5 \text { traps/ha for mass trapping. Tying yellow sticky trap to } \\
\text { attract whiteflies. Spraying Metarhizium anisopliae (Biomet) }\left(2 \times 10^{9} / \mathrm{ml}\right) @ 3 \mathrm{~L} / \mathrm{ha} \text { and Beauveria } \\
\text { bassiana (Biorin) }\left(2 \times 10^{9} / \mathrm{ml}\right) @ 3 \mathrm{~L} / \mathrm{ha} \text { (sprayed in the evening hours) }\end{array}$ \\
\hline $\mathrm{M}_{4}$ & $\begin{array}{l}\text { Sowing maize as a barrier crop. Removal of infested leaves and residues from the appearance of pests. } \\
\text { Erection of solar light trap with yellow pan @ } 5 \text { traps/ha for mass trapping. Tying yellow sticky trap to } \\
\text { attract whiteflies. Spraying Neem oil @ } 1 \% \text { and Pongam oil @ } 1 \%\end{array}$ \\
\hline $\mathrm{M}_{5}$ & $\begin{array}{l}\text { Spraying 1. Neem oil 1\% 2. Pongam oil 1\% 3. Diafenthiuron } 50 \text { WP @ } 0.80 \mathrm{~g} / 1 \text { and } 4 \text {. Triazophos } 40 \text { EC } \\
@ 1.5 \mathrm{ml} / 1\end{array}$ \\
\hline $\mathrm{M}_{6}$ & Spraying 1. M. anisopliae $\left(2 \times 10^{9}\right)$ 2. B. bassiana $\left(2 \times 10^{8}\right) 3$. Neem oil $1 \%$ and 4 . Pongam oil $1 \%$ \\
\hline $\mathrm{M}_{7}$ & $\begin{array}{l}\text { Spraying 1. M. anisopliae }\left(2 \times 10^{9} / \mathrm{ml}\right) \text { 2. B. bassiana }\left(2 \times 10^{9} / \mathrm{ml}\right) 3 . \text { Diafenthiuron } 50 \text { WP @ } 0.80 \mathrm{~g} / 1 \text { and } \\
\text { 4. Triazophos40 EC @ } 1.5 \mathrm{ml} / 1\end{array}$ \\
\hline $\mathrm{M}_{8}$ & $\begin{array}{l}\text { Spraying 1. Diafenthiuron 50 WP @ } 0.80 \mathrm{~g} / \mathrm{L} \text { 2. Triazophos } 40 \mathrm{EC} @ 1.5 \mathrm{ml} / 1 \\
\text { 3. Buprofezin 25SC @ 0.25ml/1 and 4. Imidacloprid 17.8 SL @ } 0.35 \mathrm{ml} / 1\end{array}$ \\
\hline $\mathrm{M}_{9}$ & Untreated control \\
\hline
\end{tabular}

disease infestations were recorded from $10^{\text {th }}$ day after planting and continued up to 110 days. All the data set were subjected to pooled analysis of variance (ANOVA) after appropriate transformations according to Gomez and Gomez (1984).

\section{RESULTS AND DISCUSSION}

The impact of eight IPM modules on natural enemies were recorded for two seasons, kharif 2017 and rabi-summer 2017-18. Four observations were recorded at 30, 50, 70 and 80 days after planting (DAP). There was a significant difference among the modules in the number of natural enemies per plant on an average. Prominent natural enemies viz. coccinellids (Coccinella septempunctata (L.) and Menochilus sexmaculatus (Fab.)), syrphid (Eristalis quinquestriatus), hymenopteran Encarsia guadeloupae (Viggiani) and spiders Phytoseiulus sp, Amblyseius spp. were recorded during the study (Table 2).

In general, it was found that during rabi-summer, the population of $B$. tabaci on bitter gourd was higher compared to kharif season it. As a numerical response, the population of natural enemies was also higher compared to the kharif season (Table 3). When modules were compared for the
B. tabaci population, modules 1 to 4 (sowing maize as a barrier crop, removal of infested leaves and residues from the appearance of pests, erection of solar light trap with yellow pan@ 5 traps/ha for trapping, tying yellow sticky trap to attract whiteflies (Plate 1), spraying neem oil @ 1\% and pongam oil @1\%) and module 6 (Spraying M. anisopliae $\left(2 \times 10^{9}\right)$, B. bassiana $\left(2 \times 10^{8}\right)$, Neem oil $1 \%$ and Pongam oil $\left.1 \%\right)$ which

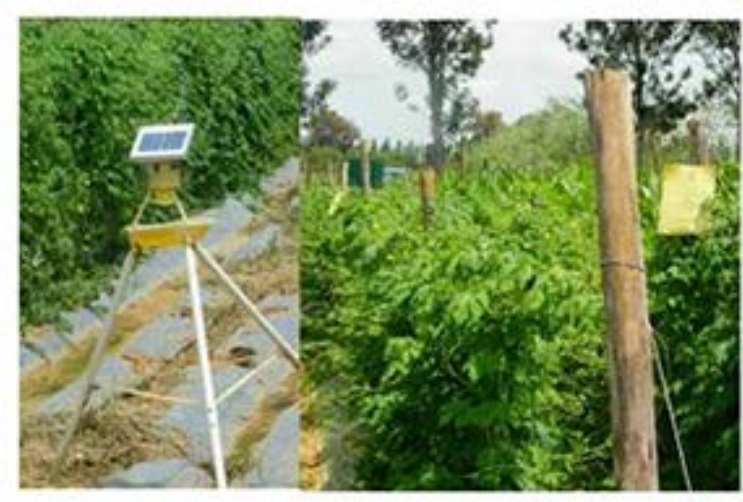

Plate 1. Solar light trap with yellow pan and yellow sticky trap used for trapping whiteflies. 
Table 2. Natural enemies recorded on whiteflies in bitter gourd ecosystem

\begin{tabular}{|c|c|c|c|}
\hline Coleopterans & Chrysopids and Syrphids & Hymeno-pterans & Spiders \\
\hline Coccinellidae: Lady bird beetle, & Chrysopidae: Green lace & & \\
Coccinella septempunctata (L.), & $\begin{array}{c}\text { wing, Chrysoperla zastrowi } \\
\text { sillemi (Esben-Peterson) }\end{array}$ & Parasitoid -Encarsia & Predatory mites, \\
Menochilus sexmaculatus (Fab.) & Syrphidae: Syrphid fly, & guadeloupae Viggiani & Amblyseius spp. \\
Staphilinidae: Rove beetle, & Eristalis quinquestriatus & & Phytoseiidae \\
Paederus fuscipes (Curtis) & (Fab.) & & \\
\hline
\end{tabular}

Table 3. Effect of IPM modules on natural enemies in bitter gourd ecosystem, kharif $^{*}$

\begin{tabular}{|c|c|c|c|c|c|c|c|c|c|c|}
\hline \multirow[b]{2}{*}{ Modules } & \multicolumn{5}{|c|}{ No. of coccinellids / plant } & \multicolumn{5}{|c|}{ No. of syrphids / plant } \\
\hline & $\begin{array}{c}30 \\
\text { DAP }\end{array}$ & $\begin{array}{c}50 \\
\text { DAP }\end{array}$ & $\begin{array}{c}70 \\
\text { DAP }\end{array}$ & $\begin{array}{c}90 \\
\text { DAP }\end{array}$ & Mean & 30 DAP & $\begin{array}{c}50 \\
\text { DAP }\end{array}$ & $\begin{array}{c}70 \\
\text { DAP }\end{array}$ & $\begin{array}{c}90 \\
\text { DAP }\end{array}$ & Mean \\
\hline M1 & 2.22 & 2.67 & 2.22 & 2.22 & 2.33 & 1.89 & 2.11 & 1.89 & 1.56 & 1.86 \\
\hline M2 & 1.89 & 2.89 & 2.22 & 2.22 & 2.31 & 1.78 & 2.22 & 1.67 & 1.67 & 1.83 \\
\hline M3 & 2.11 & 2.56 & 2.33 & 2.33 & 2.33 & 1.67 & 2.22 & 1.78 & 1.67 & 1.83 \\
\hline M4 & 2.33 & 2.78 & 2.22 & 2.22 & 2.39 & 1.89 & 2.33 & 1.67 & 1.67 & 1.89 \\
\hline M5 & 1.11 & 1.22 & 1.22 & 1.11 & 1.17 & 0.89 & 1.11 & 0.89 & 1.11 & 1.00 \\
\hline M6 & 2.11 & 2.56 & 2.11 & 2.33 & 2.28 & 1.78 & 2.22 & 1.67 & 1.67 & 1.83 \\
\hline M7 & 1.11 & 1.44 & 1.11 & 1.11 & 1.19 & 1.11 & 0.89 & 1.11 & 0.89 & 1.00 \\
\hline M8 & 0.56 & 0.89 & 0.67 & 0.56 & 0.67 & 0.56 & 0.56 & 0.56 & 0.44 & 0.53 \\
\hline M9 & 2.11 & 2.78 & 2.22 & 2.33 & 2.36 & 1.78 & 2.22 & 1.78 & 1.67 & 1.86 \\
\hline $\operatorname{SEM}( \pm)$ & \multicolumn{5}{|c|}{0.12} & \multicolumn{5}{|c|}{0.11} \\
\hline $\mathrm{CD}(\mathrm{P}=0.05)$ & \multicolumn{5}{|c|}{0.37} & \multicolumn{5}{|c|}{0.34} \\
\hline $\mathrm{CV}(\%)$ & \multicolumn{5}{|c|}{12.74} & \multicolumn{5}{|c|}{14.71} \\
\hline \multirow[b]{2}{*}{ Modules } & \multicolumn{5}{|c|}{ No. of hymenopterans / plant } & \multicolumn{5}{|c|}{ No. of spiders / plant } \\
\hline & $\begin{array}{c}30 \\
\text { DAP }\end{array}$ & $\begin{array}{c}50 \\
\text { DAP }\end{array}$ & $\begin{array}{c}70 \\
\text { DAP }\end{array}$ & $\begin{array}{c}90 \\
\text { DAP }\end{array}$ & Mean & 30 DAP & $\begin{array}{c}50 \\
\text { DAP }\end{array}$ & $\begin{array}{c}70 \\
\text { DAP }\end{array}$ & $\begin{array}{c}90 \\
\text { DAP }\end{array}$ & Mean \\
\hline M1 & 2.11 & 1.89 & 1.44 & 1.11 & 1.64 & 2.22 & 1.89 & 1.67 & 1.11 & 1.72 \\
\hline M2 & 1.89 & 1.78 & 1.44 & 1.22 & 1.58 & 2.11 & 1.89 & 1.56 & 1.22 & 1.69 \\
\hline M3 & 2.11 & 1.89 & 1.56 & 1.22 & 1.69 & 2.22 & 1.78 & 1.67 & 1.22 & 1.72 \\
\hline M4 & 2.22 & 1.67 & 1.44 & 1.33 & 1.67 & 2.11 & 1.89 & 1.67 & 1.33 & 1.75 \\
\hline M5 & 1.11 & 1.12 & 0.89 & 0.78 & 0.97 & 1.11 & 1.11 & 1.11 & 0.78 & 1.03 \\
\hline M6 & 2.11 & 1.89 & 1.44 & 1.22 & 1.67 & 2.22 & 1.89 & 1.89 & 1.22 & 1.81 \\
\hline M7 & 0.89 & 1.11 & 0.89 & 0.89 & 0.94 & 0.89 & 1.22 & 1.11 & 0.67 & 0.97 \\
\hline
\end{tabular}




\begin{tabular}{|c|c|c|c|c|c|c|c|c|c|c|}
\hline M8 & 0.56 & 0.44 & 0.22 & 0.22 & 0.36 & 0.33 & 0.44 & 0.33 & 0.44 & 0.39 \\
\hline M9 & 2.11 & 1.89 & 1.44 & 1.22 & 1.67 & 2.22 & 1.89 & 1.67 & 1.22 & 1.75 \\
\hline $\operatorname{SEM}( \pm)$ & \multicolumn{5}{|c|}{0.17} & \multicolumn{5}{|c|}{0.17} \\
\hline $\mathrm{CD}(\mathrm{P}=0.05)$ & \multicolumn{5}{|c|}{0.52} & \multicolumn{5}{|c|}{0.54} \\
\hline CV (\%) & \multicolumn{5}{|c|}{24.79} & \multicolumn{5}{|c|}{24.33} \\
\hline
\end{tabular}

*Note: Pooled data of kharif for two seasons 2016 and 2017

Table 4. Effect of IPM modules on natural enemies in bitter gourd ecosystem, rabi-summer*

\begin{tabular}{|c|c|c|c|c|c|c|c|c|c|c|}
\hline \multirow{2}{*}{ Modules } & \multicolumn{5}{|c|}{ No. of coccinellids/plant } & \multicolumn{5}{|c|}{ No. of syrphids/plant } \\
\hline & $\begin{array}{c}30 \\
\text { DAP }\end{array}$ & $\begin{array}{c}50 \\
\text { DAP }\end{array}$ & $\begin{array}{c}70 \\
\text { DAP }\end{array}$ & $\begin{array}{c}90 \\
\text { DAP }\end{array}$ & Mean & $\begin{array}{c}30 \\
\text { DAP }\end{array}$ & $\begin{array}{c}50 \\
\text { DAP }\end{array}$ & $\begin{array}{c}70 \\
\text { DAP }\end{array}$ & $\begin{array}{c}90 \\
\text { DAP }\end{array}$ & Mean \\
\hline M1 & 2.44 & 3.33 & 3.44 & 4.33 & 3.39 & 2.67 & 2.56 & 2.44 & 2.56 & 2.56 \\
\hline M2 & 2.33 & 3.44 & 2.89 & 4.44 & 3.28 & 2.78 & 2.44 & 2.56 & 2.56 & 2.58 \\
\hline M3 & 2.22 & 3.44 & 3.67 & 4.22 & 3.39 & 2.89 & 2.56 & 2.33 & 2.67 & 2.61 \\
\hline M4 & 2.33 & 3.33 & 3.11 & 4.56 & 3.33 & 2.78 & 2.56 & 2.56 & 2.44 & 2.58 \\
\hline M5 & 1.22 & 1.33 & 1.33 & 1.44 & 1.33 & 1.11 & 1.11 & 0.89 & 1.33 & 1.11 \\
\hline M6 & 2.33 & 3.22 & 3.56 & 4.44 & 3.39 & 2.89 & 2.89 & 2.67 & 2.56 & 2.75 \\
\hline M7 & 1.23 & 1.89 & 1.44 & 1.33 & 1.48 & 1.33 & 0.89 & 1.11 & 1.33 & 1.17 \\
\hline M8 & 0.67 & 0.89 & 0.78 & 0.89 & 0.81 & 0.67 & 0.67 & 0.56 & 0.56 & 0.61 \\
\hline M9 & 2.44 & 3.44 & 3.67 & 4.56 & 3.53 & 2.78 & 2.56 & 2.78 & 2.67 & 2.69 \\
\hline $\operatorname{SEM}( \pm)$ & \multicolumn{5}{|c|}{0.36} & \multicolumn{5}{|c|}{0.08} \\
\hline $\mathrm{CD}(\mathrm{P}=0.05)$ & \multicolumn{5}{|c|}{1.10} & \multicolumn{5}{|c|}{0.25} \\
\hline $\mathrm{CV}$ & \multicolumn{5}{|c|}{26.98} & \multicolumn{5}{|c|}{7.60} \\
\hline \multirow{2}{*}{ Modules } & \multicolumn{5}{|c|}{ No. of hymenopterans/plant } & \multicolumn{5}{|c|}{ No. of spiders/plant } \\
\hline & $\begin{array}{c}30 \\
\text { DAP }\end{array}$ & $\begin{array}{c}50 \\
\text { DAP }\end{array}$ & $\begin{array}{c}70 \\
\text { DAP }\end{array}$ & $\begin{array}{c}90 \\
\text { DAP }\end{array}$ & Mean & $\begin{array}{c}30 \\
\text { DAP }\end{array}$ & $\begin{array}{c}50 \\
\text { DAP }\end{array}$ & $\begin{array}{c}70 \\
\text { DAP }\end{array}$ & $\begin{array}{c}90 \\
\text { DAP }\end{array}$ & Mean \\
\hline M1 & 2.56 & 2.89 & 3.11 & 3.11 & 2.92 & 2.78 & 3.89 & 4.11 & 4.78 & 3.89 \\
\hline M2 & 2.44 & 2.78 & 2.78 & 2.89 & 2.72 & 2.56 & 3.33 & 4.22 & 4.89 & 3.75 \\
\hline M3 & 2.33 & 3.11 & 2.89 & 3.11 & 2.86 & 2.56 & 3.44 & 3.78 & 4.89 & 3.67 \\
\hline M4 & 2.44 & 2.89 & 3.11 & 3.11 & 2.89 & 2.44 & 3.78 & 4.33 & 4.78 & 3.83 \\
\hline M5 & 1.22 & 1.22 & 1.44 & 1.78 & 1.42 & 1.11 & 1.44 & 1.44 & 1.67 & 1.42 \\
\hline M6 & 2.33 & 3.11 & 3.11 & 3.33 & 2.97 & 2.67 & 3.67 & 4.44 & 4.78 & 3.89 \\
\hline M7 & 0.89 & 1.33 & 1.78 & 1.89 & 1.47 & 0.89 & 1.33 & 1.44 & 1.67 & 1.33 \\
\hline M8 & 0.67 & 0.89 & 0.78 & 0.56 & 0.72 & 0.56 & 0.89 & 0.78 & 0.67 & 0.72 \\
\hline M9 & 2.56 & 3.11 & 3.15 & 3.22 & 3.01 & 2.78 & 3.89 & 4.54 & 4.89 & 4.03 \\
\hline
\end{tabular}




\begin{tabular}{|c|c|c|}
\hline $\mathrm{SEM}( \pm)$ & 0.16 & 0.39 \\
\hline $\mathrm{CD}(\mathrm{P}=0.05)$ & 0.49 & 1.22 \\
\hline $\mathrm{CV}$ & 13.77 & 26.76 \\
\hline
\end{tabular}

*Note: Pooled data of rabi-summer for two seasons 2016-17 and 2017-18

do not include frequent insecticidal applications recorded higher number of coccinellids, syrphids, hymenopterans and spiders than the IPM modules where frequent application of chemical insecticides were included as a treatment (Table 4).

\section{Yield and benefit - cost ratio (BCR)}

The IPM modules were evaluated for two seasons, i.e. kharif-2016, 2017 and rabi-summer 2016 - 17 and 2017 - 18. During kharif, all the modules gave significantly higher yields than the control (5.77 t/ha). Module 10 and 6 gave the highest yield of 10.27 and $10.06 \mathrm{t} / \mathrm{ha}$, followed by Module 5 (9.97 $\mathrm{t} / \mathrm{ha}$ ) and Module 7 and 4 (9.64 and 9.38t/ha), respectively. By considering the economics, Module 6 recorded higher BCR (2.70) and ranked first among all the IPM trials evaluated, followed by Module 4 (2.62). The control gave BCR of 1.77 only (Table. 5). The BCR among all the trials, except control, all modules gave good results and were at-par with each other. followed by $10.39,10.24$ and 10.09 t/ha in modules 8,5 and 7 respectively. As per the economics, the module 6 recorded higher BCR (2.82), followed by module 44 (2.76) and module 7 (2.67). Control plot gave cost-benefit ratio of 1.83. Overall, based on BCR values obtained from the different modules tested, it was observed that were significantly superior and were at-par with each other except the control.

There were statistical significant differences in the population of natural enemies among the different modules. The IPM modules, where the number of natural enemies was higher, recorded the lower Bemisia tabaci infestation and consequently had higher yields. This is a reflection of the action of natural enemies on whitefly population and in turn on the bitter gourd crop yields. The results are in-line with Nisha Lekshmi (2013) who reported the activity of coccinellids was at peak in summer compared to kharif. There were

Table 5. Effect of IPM modules on bitter gourd yield

\begin{tabular}{|c|c|c|c|c|c|c|}
\hline \multirow[b]{2}{*}{ Module No. } & Kharif & Rabi-summer & \multirow{2}{*}{$\begin{array}{c}\text { Mean } \\
\text { (in tons)/ha }\end{array}$} & Kharif & Rabi-summer & \multirow{2}{*}{$\begin{array}{l}\text { Mean } \\
\text { BCR }\end{array}$} \\
\hline & $\begin{array}{c}\text { Yield } \\
\text { (in tons)/ha }\end{array}$ & $\begin{array}{c}\text { Yield } \\
\text { (in tons)/ha }\end{array}$ & & $\mathrm{BCR}$ & $\mathrm{BCR}$ & \\
\hline 1 & $8.08 \mathrm{e}$ & $7.96 \mathrm{e}$ & $8.02 \mathrm{c}$ & 2.34 & 2.30 & 2.32 \\
\hline 2 & $9.06 \mathrm{~d}$ & $8.78 \mathrm{~d}$ & $8.92 \mathrm{c}$ & 2.55 & 2.47 & 2.51 \\
\hline 3 & $9.78 \mathrm{c}$ & $9.60 \mathrm{c}$ & $9.69 b$ & 2.55 & 2.50 & 2.53 \\
\hline 4 & $9.86 b c$ & $9.38 \mathrm{c}$ & $9.62 b$ & 2.76 & 2.62 & 2.69 \\
\hline 5 & 10.24 & $9.97 \mathrm{~b}$ & $10.10 \mathrm{ab}$ & 2.52 & 2.45 & 2.49 \\
\hline 6 & $10.50 \mathrm{a}$ & $10.06 \mathrm{a}$ & $10.28 \mathrm{a}$ & 2.82 & 2.70 & 2.76 \\
\hline 7 & $10.09 \mathrm{ab}$ & $9.64 c$ & $9.86 \mathrm{ab}$ & 2.67 & 2.56 & 2.61 \\
\hline 8 & $10.39 \mathrm{a}$ & $10.27 \mathrm{a}$ & $10.33 \mathrm{a}$ & 2.61 & 2.58 & 2.60 \\
\hline 9 & $5.97 \mathrm{f}$ & $5.77 \mathrm{f}$ & $5.87 \mathrm{e}$ & 1.83 & 1.77 & 1.80 \\
\hline $\operatorname{SEm}( \pm)$ & 0.15 & 0.12 & 0.14 & - & - & - \\
\hline CV $(\%)$ & 0.42 & 0.38 & 0.39 & - & - & - \\
\hline $\mathrm{CD} @ 5 \%$ & 2.85 & 2.37 & 2.52 & - & - & - \\
\hline
\end{tabular}

\# Modules (Treatments) values in the column with different alphabets are statistically significant $(\mathrm{p}=0.05)$

During rabi-summer 2017-18, the same set of IPM modules were evaluated. Same trend was observed in all the modules and it gave significantly higher yields than the control $(5.97 \mathrm{t} / \mathrm{ha}$ ). Module 6 gave the highest yield of $10.50 \mathrm{t} / \mathrm{ha}$ and statistical significant differences in the population of natural enemies among the different bio-rational modules (Kedar et al., 2014). Sardana et al., (2006) reported significantly higher populations of coccinellids, 
predatory spiders and Chrysoperla in IPM field of bitter gourd plant. Rao et al. (1989) on mungbean and urdbean and Gurlaz and Sangha (2016) on chilli, reported that the B. tabaci was predated by coccinellids, Verania vincta, Menochilus sexmaculata, Chrysoperla zastrowi sillemi and the phytoseiid, Amblyseius sp. Three coccinellid predators namely, B. suturalis, $S$. parcesetosum and $C$. sexmaculata were observed on whiteflies. Whiteflies are known to be attracted to the yellow range of the natural light. The yellow colour can attract more whiteflies. Chu et al. (2000) could prove that the most attractive colours in a wavelength range between 490 to $600 \mathrm{~nm}$ for Bemisia argentifolli were yellow-green, yellow and spring green respectively. Mutwiwa and Tantau (2005) also reported that the greenhouse whitefly, Trialeuodes vaporariorum, were attracted to lamps of the yellow colour.

Hence the present research findings indicate that module 6 (Spraying of M. anisopliae $\left(2 \times 10^{9}\right)$, B. bassiana $\left(2 \times 10^{8}\right)$, neem oil $1 \%$ and pongam oil $1 \%$ ) which do not include frequent insecticidal applications recorded higher number of coccinellids, syrphids, hymenopterans and spiders than the IPM modules where frequent applications of chemical insecticides were included as a treatment. Module 6 also gave the highest yield and BCR in all cases.

\section{ACKNOWLEDGEMENT}

We acknowledge the taxonomist of University of Agricultural Sciences, Bengaluru for identifying the insects.

\section{REFERENCES}

Asiimwe P, Ecaat JS, Guershon M, Kyamanywa S, Gerling D, Legg JP. 2007. Evaluation of Serangium sp. (Col., Coccinellidae), a predator of Bemisia tabaci (Hom., Aleyrodidae) on cassava. J Appl Entomol. 131: 76-80. https://doi.org/10.1111/j.1439-0418.2006.01122.x.

Atuncha A, Amata EAR, Mwirichia R, Kasina M, Mbevi B, Wakoli E. 2013. Evaluation of predation potential of coccinellids on cassava whiteflies. $J$ Entomol Nematol. 5: 84-87. https://doi.org/10.5897/JEN2012.022.

Chu CC, Pinter PJJ, Henneberry TJ, Umeda K, Nawick ET, Wei YA, Reddy VR, Shrepatis M. 2000. Use of CC Traps with different trap base colors for silverleaf whiteflies (Homoptera: Aleyrodidae), thrips (Thysanoptera: Thripidae), and leafhoppers (Homoptera: Cicadellidae) J Econ Entomol. 93: 1329. https://doi.org/10.1603/0022-0493-93.4.1329.

Gerling D, Alomar O, Arno J. 2001. Biological control of Bemisia tabaci using predators and parasitoids. Crop
Prot. 20: 779-799. https://doi.org/10.1016/S02612194(01)00111-9.

Gomez KA, Gomez AA. 1984. Statistical Procedures for Agricultural Research. 2nd Edn., John Wiley and Sons Inc., New York, USA; p. 680. ISBN: 13-9780471879312.

Gurlaz Kaur, Sangha KS. 2016. Diversity of arthropod fauna associated with chilli (Capsicum annuum L.) in Punjab. J Entomol Zool Studies 4(5): 390-396.

Kapadia MN, Puri SN. 1991. Biology and comparative predation efficacy of three heteropteran species recorded as predators of Bemisia tabaci in Maharashtra. Entomophaga 36: 555-559. https://doi.org/10.1007/ BF02374438.

Kedar SC, Saini RK, Kumaranag KM, Sharma SS. 2014. Record of natural enemies of whitefly, Bemisia tabaci (Gennadius) (Hemiptera: Aleyrodidae) in some cultivated crops in Haryana. J Biopestic. 7(1): 57-59.

Li SJ, Xue X, Ahmed MZ, Ren SX, DuYZ, Wu JH, Cuthbertson AGS, Qiu BL. 2011. Host plants and natural enemies of Bemisia tabaci (Hemiptera: Aleyrodidae) in China. J Insect Sci. 18: 101-120. https://doi.org/10.1111/ j.1744-7917.2010.01395.x.

Mutwiwa UN, Tantau HJ. 2005. Agricultural Engineering International. CIGRE J. Vol. VII.

Natarajan K. 1990. Natural enemies of Bemisia tabaci Genn. and effect of insecticides on their activity. J Biol Control 4: $86-88$.

Nisha Lekshmi. 2013. Evaluation of different Integrated Pest Management components against fruit fly (Bactrocera Cucurbitae Coquillet) and whiteflies (Bemisia Tabaci Genn.) in bitter gourd (Momordica Charantia L.). PhD Thesis submitted to IARI, New Delhi. http://krishikosh.egranth.ac.in/ handle/1/5810009838.

Nordlund DA, Legaspi JC. 1996. Whitefly predators and their potential for use in biological control. Pp. 499-513. In: Gerling D and Mayer RT (Eds.). Bemisia 1995: Taxonomy, Biology, Damage, Control and Management. Intercept Ltd, Andover, Hants, U.K..

Oliveira MRV, Henneberry TJ, Anderson PK. 2001. History, current status and collaborative research projects for Bemisia tabaci. Crop Prot. 20: 709-723.https://doi. org/10.1016/S0261-2194(01)00108-9. 
Palaniswami MS, Antony B, Vijayan SL, Henneberry TJ. 2001. Sweet potato whitefly Bemisia tabaci: Ecobiology, host interaction and natural enemies. Entomon 26: $256-262$.

Rao NV, Reddy AS, Rao KT. 1989. Natural enemies of cotton whitefly, Bemisia tabaci Genn. in relation to host population and weather factors. $J$ Biol Control 3: 10-12. https://doi.org/10.1017/S1742758400021822.
Sardana HR, Bambawale OM, Singh DK and Kadu LN. 2006. Conservation of natural enemies through IPM in brinjal (Solanum melongena L.) fields. Entomon 31(2): 83-88.

Torres LC, Lourencao AL, Costa VA, Souza B, Costa MB, Tanque RL. 2014. Records of natural enemies of Bemisia tabaci (Genn.) (Hemiptera: Aleyrodidae) Biotype B in Brazil. Neotrop Entomol. 43: 189-191. https://doi. org/10.1007/s13744-013-0188-3. 